\title{
Spinal Subdural Hematoma in Association with Anticoagulant Therapy
}

\author{
NEVILLE RUSSELL, F.B. MAROUN, J.C. JACOB
}

SUMMARY: $A$ case of spinal subdural hematoma occurring in association with anticoagulant therapy is reported. Seven similar cases from the literature are reviewed with emphasis on the clinical features, investigation, and the results of treatment. The prognosis for recovery is good, only if the condition is diagnosed and the clot evacuated before severe spinal cord compression and subsequent ischemic necrosis has occurred.

RÉSUMÉ: Nous rapportons un cas d'hématome spinal sous-dural se produisant en association avec la thérapie aux anticoagulants. Nous passons en revue sept cas semblables dans la littérature et insistons surtout sur les aspects cliniques, sur les investigations et sur les résultats du traitement. Le prognostic de récupération est hon. mais seulement si l'événement est diagnostiqué et le caillot évacué avant que ne s'établisse la compression sévère de la moelle spinale et la nécrose ischémique subséquente.

From the Division of Neurosurgery and Neurology, St. John's General Hospital - Health Science Complex and Memorial University of Newfoundland. St John's, Newfoundland, Canada.

Reprint requests to: Dr. N.A. Russell, Suite 308 , 1081 Carling Avenue, Ottawa, Ontario, K1Y 4G2, Canada.

\section{INTRODUCTION}

Spinal subdural hematoma occurring as a result of anticoagulant therapy is a rare cause of spinal cord compression. The therapeutic implications are important because early recognization and surgical decompression may prevent permanent spinal cord damage. A recent case report and review (Guthikonda et al., 1979) stated that only two cases had been reported. In fact, there are seven reports of anticoagulant related spinal subdural hematomas (Cloward and Yuhl, 1955; Tricot et al, 1964; Levy and Stula, 1971; De Angelis, 1972; Kohli et al, 1974; Guthikonda, 1979). Two other probable cases have been reported (Shaake and Schafer, 1970; Messer et al, 1976), but the details were insufficient to permit analysis. The case reported here is the eighth.

\section{CASE REPORT}

A 66 year old woman had an aortic valve prosthesis inserted in 1974 because of rheumatic heart disease. Anticoagulant therapy was begun and maintained with warfarin sodium $5 \mathrm{mg}$. daily. Four days prior to admission, she suddenly developed severe back pain localized to the mid portion of the thoracic spine. Over the next several hours, the pain radiated into her legs and weakness and numbness occurred. Twenty-four hours after onset she was unable to move her legs or to pass urine. She was treated at home for a further three days and then transferred to the St. John's General Hospital. On the day prior to admission, fever developed and she complained of headache and neck stiffness.

Examination on admission showed a complete flaccid areflexic paraplegia. Sensation to pin-prick was absent below T-6. She was incontinent of urine and the anus was patulous. Neck stiffness and fever $\left(39.2^{\circ} \mathrm{C}\right)$ was present. Prothrombin time was $19 / 12$; partial thromboplastin time 42/40. At lumbar puncture for myelography, the CSF was found to contain old, dark blood. The myelogram demonstrated a complete block to the passage of contrast material at T-9.

An immediate laminectomy, extending from T-7 to T-9 inclusive, was performed. The dura was blue and tense. Upon opening it, semi-liquid, dark blood clot extruded itself under pressure. A number 8 French red rubber catheter was inserted into the subdural space in both cephalad and caudad directions and the whole clot was removed with the aid of saline irrigation. Spinal cord pulsation returned. Water tight closure without drainage was effected.

There was no neurologic improvement in the post-operative period. She recovered from the surgery and several weeks later was transferred to a spinal rehabilitation unit. At examination six months later, no improvement was noted.

\section{ANALYSIS}

A review of table 1 shows that the 8 cases were equally distributed between the sexes. The age range was from 1980 years, the average being 55 . Three were receiving warfarin, one bishydroxycoumarin, one heparin and the others unspecified coumarin products. In 4 patients, the prothrombin times immediately preceding the onset of symptoms were specified, but in the others this information was not given. Lumbar puncture was considered to be the main cause of the hematoma in 2 cases, but no precipitating factor was identified in the others. All patients had back pain which progressed to paraplegia over a few hours to several days. The spinal level involved was usually the mid to lower thoracic, but the extent of the hematoma over many segments was shown by one of the cases which came to autopsy (Tricot et al, 1964). Six cases were treated by laminectomy and removal of the clot. Recovery occurred in only 2 (Kohli et al, 1974; Levy and Stula, 1971). Two cases (Tricot et al, 1964; De Angelis, 
TABLE I

Synopsis of Eight Cases of Anticoagulant Associated Spinal Subdural Hematoma

\begin{tabular}{|c|c|c|c|c|c|c|c|c|c|c|}
\hline Case & Author & Age/Sex & $\begin{array}{l}\text { Indication for } \\
\text { Anticoagulants }\end{array}$ & Anticoagulants & $\begin{array}{c}\text { Prothrombin } \\
\text { Time }\end{array}$ & $\begin{array}{l}\text { Precipitating } \\
\text { Factor }\end{array}$ & Site & $\begin{array}{l}\text { Clinical } \\
\text { Features }\end{array}$ & Surgery & Result \\
\hline 1 & $\begin{array}{l}\text { Cloward } \\
\text { et al } \\
1955\end{array}$ & $66 / M$ & $\begin{array}{l}\text { myocardial } \\
\text { infarction }\end{array}$ & $\begin{array}{l}\text { bishydroxy- } \\
\text { coumarin }\end{array}$ & $11 \%$ & $\begin{array}{l}\text { none } \\
\text { identified }\end{array}$ & $\begin{array}{l}\text { T11 - } \\
\text { L1 }\end{array}$ & $\begin{array}{l}\text { back pain, neck } \\
\text { stiffness, leg } \\
\text { pain, para- } \\
\text { plegia over } \\
5 \text { days }\end{array}$ & yes & $\begin{array}{l}\text { minimal } \\
\text { recovery }\end{array}$ \\
\hline 2 & $\begin{array}{l}\text { Tricot } \\
\text { et al } \\
1964\end{array}$ & $53 / F$ & $\begin{array}{l}\text { cardiac } \\
\text { arrhythmia }\end{array}$ & $\begin{array}{l}\text { coumarin } \\
\text { products }\end{array}$ & $13 \%$ & $\begin{array}{l}\text { none } \\
\text { identified }\end{array}$ & $\begin{array}{l}\text { T5 - } \\
\text { conus }\end{array}$ & $\begin{array}{l}\text { back pain, } \\
\text { girdle pain } \\
\text { neck stiffness } \\
\text { paraplegia over } \\
3 \text { days }\end{array}$ & no & $\begin{array}{l}\text { no recovery } \\
\text { died } \\
\text { autopsy }\end{array}$ \\
\hline 3 & $\begin{array}{l}\text { Levy et al } \\
1971\end{array}$ & $68 / M$ & $\begin{array}{l}\text { atrial } \\
\text { fibrillation }\end{array}$ & $\begin{array}{l}\text { coumarin } \\
\text { products }\end{array}$ & $10 \%$ & $\begin{array}{l}\text { none } \\
\text { identified }\end{array}$ & $\begin{array}{l}\text { T8 } \\
\text { T } 10\end{array}$ & "paraplegia" & yes & recovery \\
\hline 4 & $\begin{array}{l}\text { Levy et al } \\
1971\end{array}$ & $80 / \mathrm{M}$ & $\begin{array}{l}\text { peripheral } \\
\text { arterial disease }\end{array}$ & $\begin{array}{l}\text { coumarin } \\
\text { products }\end{array}$ & $9 \%$ & $\begin{array}{l}\text { none } \\
\text { identified }\end{array}$ & $\begin{array}{l}\text { T6 } \\
\text { T12 }\end{array}$ & "paraplegia" & yes & no recovery \\
\hline 5 & $\begin{array}{l}\text { De Angelis } \\
1972\end{array}$ & $19 / \mathrm{F}$ & $\begin{array}{l}\text { pulmonary } \\
\text { embolus }\end{array}$ & $\begin{array}{l}\text { warfarin } \\
\text { sodium }\end{array}$ & $30 \%$ & L.P. & $T-L$ & $\begin{array}{l}\text { back pain, } \\
\text { paraplegia over } \\
\text { several days }\end{array}$ & no & $\begin{array}{l}\text { no recovery } \\
\text { died } \\
\text { autopsy }\end{array}$ \\
\hline 6 & $\begin{array}{l}\text { Kohli et } \\
\text { al } \\
1974\end{array}$ & $29 / \mathrm{M}$ & $\begin{array}{l}\text { arterial } \\
\text { trauma }\end{array}$ & heparin & $\begin{array}{l}\text { not } \\
\text { specified } \\
\text { (clotting } \\
\text { time) }\end{array}$ & L.P. & $\begin{array}{l}\text { T8 } \\
\text { L1 }\end{array}$ & $\begin{array}{l}\text { back pain, } \\
\text { paraplegia } \\
\text { several hours }\end{array}$ & yes & $\begin{array}{l}\text { complete } \\
\text { recovery }\end{array}$ \\
\hline 7 & $\begin{array}{l}\text { Guthikonda } \\
\text { et al } \\
1979\end{array}$ & $63 / \mathrm{F}$ & $\begin{array}{l}\text { mitral valve } \\
\text { prosthesis }\end{array}$ & $\begin{array}{l}\text { warfarin } \\
\text { sodium }\end{array}$ & $\begin{array}{l}\text { not } \\
\text { specified }\end{array}$ & $\begin{array}{l}\text { none } \\
\text { identified }\end{array}$ & $\begin{array}{l}\text { L3 - } \\
\text { SI }\end{array}$ & $\begin{array}{l}\text { back pain, leg } \\
\text { pain, para- } \\
\text { plegia over } 3 \\
\text { days }\end{array}$ & yes & no recovery \\
\hline 8 & $\begin{array}{l}\text { Russell et } \\
\text { al } \\
\text { (present } \\
\text { case) }\end{array}$ & $66 / F$ & $\begin{array}{l}\text { aortic valve } \\
\text { prosthesis }\end{array}$ & $\begin{array}{l}\text { warfarin } \\
\text { sodium }\end{array}$ & $\begin{array}{l}\text { not } \\
\text { specified }\end{array}$ & $\begin{array}{l}\text { none } \\
\text { identified }\end{array}$ & $\begin{array}{l}\text { T7 - } \\
\text { T9 }\end{array}$ & $\begin{array}{l}\text { back pain, neck } \\
\text { stiffness, para- } \\
\text { plegia over } 24 \\
\text { hours }\end{array}$ & yes & no recovery \\
\hline
\end{tabular}

1972) did not have surgery because of serious associated illness which ultimately lead to death. Autopsies confirmed the presence of spinal subdural hematomas in both.

\section{DISCUSSION}

Although the most common form of intraspinal hemorrhage in a patient undergoing anticoagulant therapy occurs in the epidural space (Strain, 1964; Iizuka, 1972; Levy and Stula, 1971; Sreerama et al, 1973), spinal subdural hematoma is well recognized. It presents a typical, though non specific clinical picture. Severe back pain localized to the spine often with a radicular component is the first complaint. At onset, the intensity of the pain is less severe than that seen with spinal epidural hematoma. Headache, occasionally associated with neck stiffness and fever, may occur. Trauma or straining are not usual precipitating events. The pain is followed by the development of weakness and numbness progressing to a complete sensorimotor paraplegia over a few hours to days. Prostration due to pain may cause the weakness to go unnoticed initially.

Myelography is the essential investigation. It will demonstrate partial or complete obstruction to the passage of contrast material at the hematoma site. It may be difficult to obtain CSF at lumbar puncture because of the presence of the clot. When this occurs, the myelogram must be performed via cisternal or lateral cervical puncture.

Several authors (Silverstein, 1979; Wiener and Nathanson, 1962; Snyder and Renaudin, 1977) have discussed the relationship of prothrombin activity to the likelihood of serious hemorrhage in patients undergoing anticoagulant therapy. All agree that the longer the prothrombin time, the higher the incidence of bleeding, but also note that many serious hemorrhagic complications have occurred when prothrombin times have been well within the therapeutic range. In 5 of the cases analyzed here, the prothrombin times at the time of onset of symptoms were reported. Four were within, and one below, what is considered to be a "safe" prothrombin level (between $10 \%$ and $30 \%$ - Quick 1-stage prothrombin time test). It should be noted that De Angelis (1972) stated that the method of expressing prothrombin times as a per cent of normal, is prone to technical error.

Lumbar puncture was considered a significant precipitating factor in 2 of these cases (De Angelis, 1977; Kohli et al, 1974) and in 1 which was mentioned, but not analyzed (Messer, 1976). Edelson (1974) called attention to the danger of this procedure in thrombocytopenia, reporting 8 patients 
with this condition who developed spinal subdural hematomas shortly after the puncture.

We believe that the same danger exists in a patient receiving anticoagulant therapy. If lumbar puncture in such a patient is deemed absolutely necessary, then the anti-coagulant must be discontinued and fresh frozen plasma and phytonadione or heparin antagonists administered. The procedure should be performed by the most skilled physician available, using the smallest gauge needle possible and the patient must be observed closely afterwards for the development of pain or neurologic signs (Edelson, 1974).

Spinal subdural hematoma is a neurological emergency. When a patient receiving anticoagulants develops symptoms suggestive of intraspinal hemorrhage, the anticoagulants should be immediately discontinued, appropriate antidotes administered and immediate myelography performed. Early diagnosis and prompt evacuation of the hematoma will result in a greater likelihood of recovery.

\section{REFERENCES}

CLOWARD, R.B., YUHL, E.T. (1955): Spontaneous intraspinal hemorrhage and paraplegia complicating dicoumarol therapy. Case report. Neurology (Minneap). 5: 600602.

COON, W., WILLIS, D.W. (1974): Hemorrhagic complications of anticoagulent therapy. Arch. Int. Med. 133: 386-392

DE ANGELIS, J. (1972): Hazards of subdural and epidural anaesthesia during anticoagulant therapy; a case report and review. Anaesth. Analg. Curr. Res. 51: 676-679.

EDELSON, R.N., CHERNIK, N.L., POSNER, J.B. (1974): Spinal subdural hematomas complicating lumbar puncture. Occurrence in thrombocytopenic patients. Arch. Neurol. 31: 134-137.

GUTHIKONDA, M., SCHMIDEK, H.H., WALLMAN, L.J., SNYDER, T.M. (1979): Spinal subdural hematoma: Case report and review of the literature. Neurosurgery. 5: 614-616.

IIZUKA, J. (1972): Intracranial and intraspinal hematomas associated with anticoagulant therapy. Neurochir. 15: 15-25.

KOHLI, C.M., PALMER, A.H., GRAY, G.H. (1974): Spontaneous intraspinal hemorrhage causing paraplegia. A complication of heparin therapy. Ann. Surg. 179: 197-199.

LEVY, A., STULA, D. (1971): Neurochirurgische aspektbei antikoagulantienblutungen im zentral nerven system. Dtsch. Med. Wischr. 96: 1043-1048.
MESSER, H.D., FORSHAN, V.R., BRUST, J.C.M. and HUGHES, J.E.O. (1976): Transient paraplegia from hematoma after lumbar puncture; a consequence of anticoagulant therapy. Jama. 235: 529-530.

SHAAKE, T.H., SHAFFER, E.R, (1970); Spontaneous hemorrhage in the spinal canal. (Abstr.) J. Neurol. Neurosurg. Psychiat. 33: 715-716.

SILVERSTEIN, A. (1979): Neurological complication of anticoagulant therapy; a neurologist's review. Arch. Int. Med. 139: 217220.

SNYDER, M., RENAUDIN, J. (1977): Intracranial hemorrhage associated with anticoagulant therapy. Surg. Neurol. 7: 31-34.

SREENAMA, V., IVAN, L.P., DENNERY, J.M. et al. (1973): Neurosurgical complications of anticoagulant therapy. Can. Med. Assoc. J. 108: 305-307.

STRAIN, R.E. (1964): Spinal epidural hematoma in patients on anticoagulant therapy. Ann. Surg. 159: 507-509.

TRICOT, R., NEGRETTE, P., COUMEL, P., RAGOT, M. (1964): Hemorrhagie sousdurale intraarachidienne hemorrhagie et ramollissement medullaire ou cours de traitement anticoagulent chez un mitrale. Bull. Soc. Med. Paris. 115: 627-637.

WIENER, L.M., NATHANSON, M. (1962): The relationship of subdural hematoma to anticoagulant therapy. Arch. Neurol. 6: 282286. 